\title{
Role of thermal conditions in habitat selection by hydrothermal vent gastropods
}

\author{
Amanda E. Bates ${ }^{1, *}$, Verena Tunnicliffe ${ }^{1}$, Raymond W. Lee ${ }^{2}$ \\ ${ }^{1}$ Department of Biology, University of Victoria, PO Box 3020, Victoria, British Columbia V8W 3N5, Canada \\ ${ }^{2}$ School of Biological Sciences, Washington State University, Pullman, Washington 99164-4236, USA
}

ABSTRACT: Habitat selection by 3 Juan de Fuca Ridge gastropod species relates to their thermal environment. Both collections and images taken along transects document the small-scale abundance patterns of each species with respect to temperature and distance from vent flows. Lepetodrilus fucensis and Depressigyra globulus were most abundant at distances from vent flows of 0 to $25 \mathrm{~cm}$ in warm fluids with high temperature variability $\left(10 \pm 5^{\circ} \mathrm{C}\right)$ over several time scales. Both species were also abundant at 26 to $50 \mathrm{~cm}$, where temperatures were lower with less variability $\left(4 \pm 1^{\circ} \mathrm{C}\right)$. Provanna variabilis was most abundant from 51 to $75 \mathrm{~cm}$, where temperatures were stable $\left(3 \pm 0.5^{\circ} \mathrm{C}\right)$. All species were absent where maximum fluid temperatures reached $18^{\circ} \mathrm{C}$ and their substratum coverage was related to temperature. When presented with a choice in vent fluids from 10 to $2^{\circ} \mathrm{C}$, L. fucensis and D. globulus moved to areas with temperatures above $5^{\circ} \mathrm{C}$, while $P$. variabilis showed no preference. In species-specific temperature preference experiments, L. fucensis and D. globulus aggregated between 5 and $13^{\circ} \mathrm{C}$, while $P$. variabilis occupied areas with significantly lower temperatures from 4 to $11^{\circ} \mathrm{C}$. These experimental temperature preferences correspond with their thermal environments. Upper temperature limits are moderate; extreme abiotic variability in higher temperature fluids may constrain these 3 species. We conclude thermal conditions are a primary determinant of habitat selection, thereby driving gastropod abundance patterns. However, other factors likely contribute. Space competition nearest vent flows may result in the displacement of individuals of these species to low quality habitats.

KEY WORDS: Thermal variability - Abundance patterns $\cdot$ Hydrothermal vent $\cdot$ Lepetodrilus fucensis $\cdot$ Depressigyra globulus · Provanna variabilis · Preferences

Resale or republication not permitted without written consent of the publisher

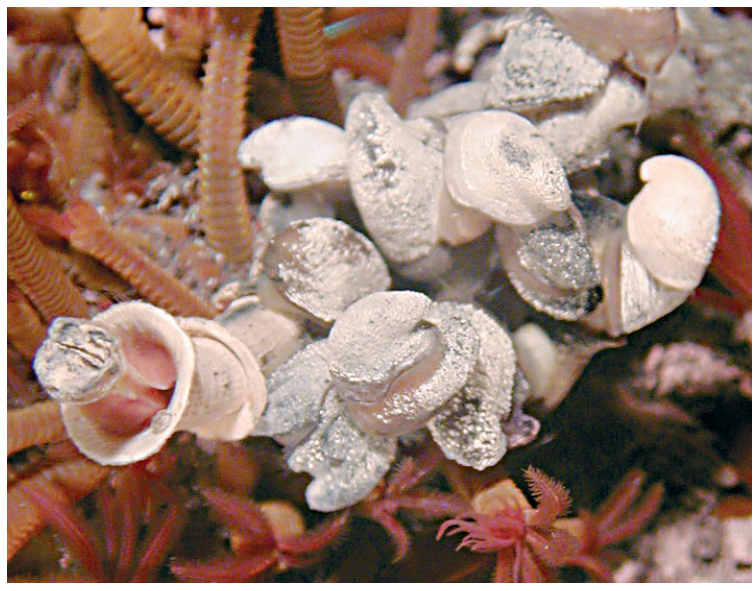

Hydrothermal vent limpets form prominent stacks at densities as high as 300000 ind. $\mathrm{m}^{-2}$ in the mixing zone between hydrothermal and deep-sea fluids. Although mean temperatures at their habitat are moderate, the limpets are exposed to haphazard fluctuations between 5 and $15^{\circ} \mathrm{C}$.

Photo: University of Victoria and I. R. MacDonald at Texas A\&M University-Corpus Christi

\section{INTRODUCTION}

The high variability of abiotic conditions in many extreme environments pose challenges to explaining species abundance patterns. Steep gradients of increasing harshness in physical and chemical conditions characterize hydrothermal vents where focused warm fluids rich in reduced compounds emerge from cracks in basalt or porous sulphide structures and mix with surrounding ambient seawater. This mixing generates rapid fluctuations in chemical variables at any fixed position (Johnson et al. 1988) that organisms must tolerate. Isolating how a specific variable such as temperature, hydrogen sul- 
phide or oxygen concentration influences faunal patterns is difficult with observational studies, as vent fluid characters are highly correlated. Furthermore, the fragmented nature of vent habitats presents another layer of complexity. Most vents are not isolated, but exist as part of a disordered field of venting sources that vary in intensity and size. In this patchy habitat, organisms persist in a complex mosaic of temporally and spatially shifting vent fluid concentration.

Many vent studies focus on key fluid characters that likely affect processes such as habitat selection and recruitment by relating abiotic factors to species patterns in the field. Because deep-sea access by researchers is time limited, variables that can be measured expeditiously and accurately constitute the majority of the data. Studies of venting vigour (Sarrazin et al. 1999), temperature (Hessler \& Smithey 1983), hydrogen sulphide and iron concentration (Sarrazin et al. 1999, Luther et al. 2001) suggest that abiotic factors relate to spatial patterns in species abundance. Observations of distinct species zones on sulphide structures (Tunnicliffe \& Juniper 1990) and around basalt-hosted vents (Fustec et al. 1987) support the hypothesis that fauna select specific conditions at larval and/or adult stages. Larval studies show that patterns in species richness and abundance on settlement plates are related to temperature, suggesting recruitment processes are influenced by abiotic factors (Mullineaux et al. 2000).

Behavioural responses to habitat variables are largely unexplored for hydrothermal vent fauna (Van Dover \& Lutz 2004). In comparison, decades of observational and experimental work from intertidal habitats demonstrate that animals exhibit flexible behavioural re- sponses to various environmental cues. Complex species interactions act in concert with these responses to determine abundance patterns (Underwood et al. 2004). While we have yet to build such complex models in hydrothermal habitats, preliminary work can identify the importance of specific abiotic factors to species abundance patterns. Multiple approaches have successfully linked faunal patterns on intertidal shores to species-specific selection of habitats based on abiotic factors (Chapman 2000).

Thermal conditions are primary determinants of habitat selection by marine species (Heath et al. 1993, Williams \& Morritt 1995). Shorelines are a model system for research examining links between heat exposure and habitat selection. The upper distribution limits of organisms typically relate to their temperature tolerance. Avoidance by mobile species of specific temperatures occurs in gradient experiments in lab and field settings and preferred temperatures typically match environmental exposure (e.g. Pulgar et al. 2005). Heat shock can also influence the outcome of species interactions, thus altering abundance patterns (Tomenack 2002). Understanding how habitat selection relates to environment variability, organismal body temperature and physiological stress is emerging as an important research goal (see Tomenack \& Helmuth 2002). Because hydrothermal fluid temperatures are highly variable, studies aiming to link thermal conditions to habitat selection by vent fauna can contribute to this goal (Chevaldonné et al. 1991).

A remarkably high abundance of gastropods carpet the substrata around warm fluid sources at vents on the Juan de Fuca Ridge complex (Fig. 1A). The domi-
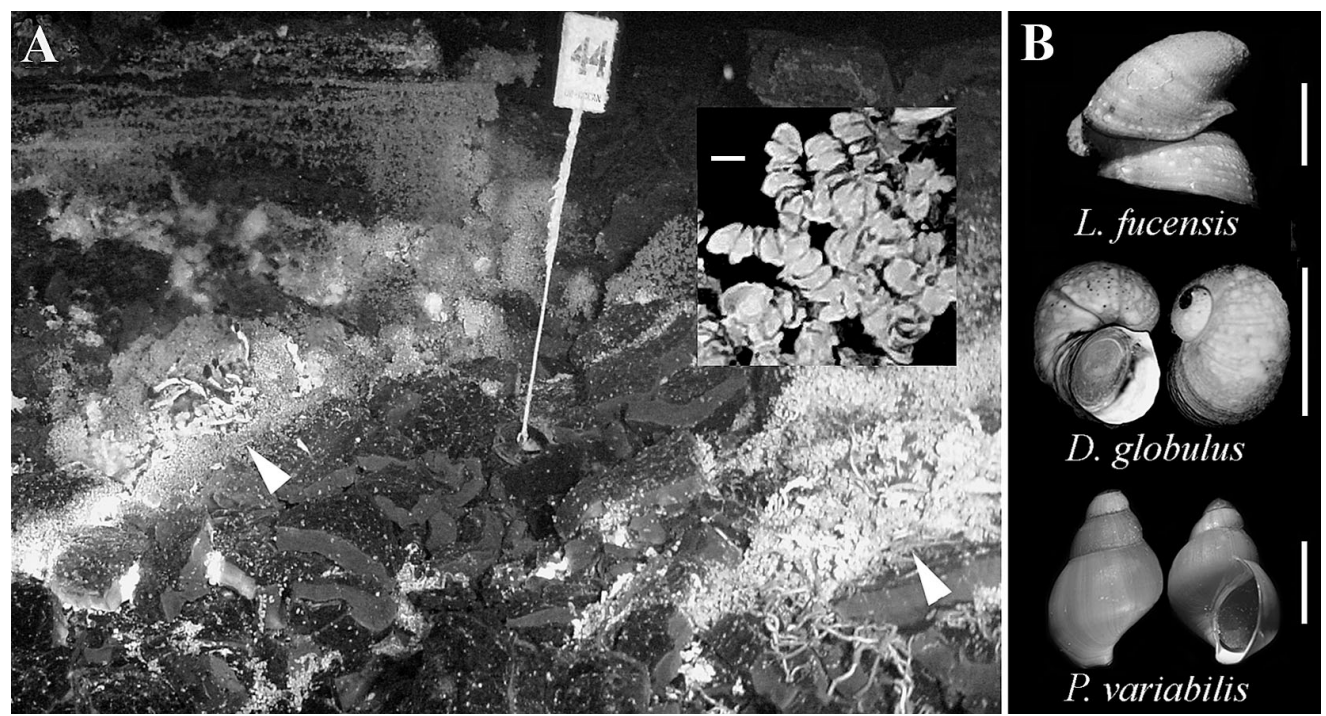

Fig. 1. Gastropods from Juan de Fuca Ridge hydrothermal vents. (A) Pillow basalts on a young lava flow near Mrk N44, South Rift Zone, Axial Volcano. Low temperature vent fluid emerges from meter-long cracks (arrowheads). Fauna clustered around venting fluids is dominated by the dense stacks of Lepetodrilus fucensis pictured in inset (scale bar $=5 \mathrm{~mm}$ ). (B) Three common gastropod species: L. fucensis, Depressigyra globulus and Provanna variabilis (scale bars $=5 \mathrm{~mm}$ ) 
nant gastropod is Lepetodrilus fucensis McLean 1988, (Fig. 1B), a non-coiling species found at densities of $10^{5}$ individuals $\mathrm{m}^{-2}$ (Sarrazin et al. 1997, Tsurumi \& Tunnicliffe 2003). Also common are 2 snails, Depressigyra globulus Warén and Bouchet 1989, and Provanna variabilis Warén and Bouchet 1986 (Fig. 1B). Abundance patterns of these species in diffuse flows may relate to fluid parameters such as sulphide-toheat ratios (Marcus 2003). Gastropod density on a sulphide structure is correlated with decimeter scale changes in key physical and chemical variables (Sarrazin et al. 1997, 1999, Sarrazin \& Juniper 1999). Zonation of these 3 species is apparent in video imagery (A. Bates pers. obs.); L. fucensis and D. globulus occur near focused vent fluids, while $P$. variabilis is visually distinct on the substratum surrounding vents. This hypothesis that $P$. variabilis may occupy a different habitat is supported by a measured increase in the relative abundance of $P$. variabilis with distance from a vent source (Marcus \& Tunnicliffe 2002).

Research conducted by submersibles can limit the scope of ecological studies by restricting the number of sampling and experimental replicates possible. Precision in fine scale studies depends on manipulator dexterity. Hence, two lessons from observational and experimental studies in the intertidal are relevant. First, it is critical to replicate samples and experiments at different sites to generalize patterns (Chapman 2000). Second, to relate species patterns to fluid variables, sampling of each must be performed at the same scale (Chapman 2000). With these lessons in mind, the goal of this research was to use novel in situ techniques and experiments to test if the small-scale abundance patterns of vent gastropods relate to (1) variation in thermal conditions and (2) their behavioural responses to temperature. To achieve this goal, we used complementary observational and experimental approaches.

The first objective was to describe small-scale spatial patterns in the abundance of Lepetodrilus fucensis, Depressigyra globulus and Provanna variabilis with respect to thermal conditions and distance from focused vent flows using in situ transect and survey approaches. We hypothesize that these 3 species use fluid temperature to select habitat. The second objective was to test this hypothesis by determining if species-specific behavioural responses to temperature correspond with spatial patterns in their abundance. We employed image analysis of a fixed area over time and a manipulative experiment to examine whether in situ behavioural responses relate to thermal regime. To ascertain if temperature is a behavioural cue, we designed controlled experiments shipboard to test whether the 3 species prefer specific temperatures.

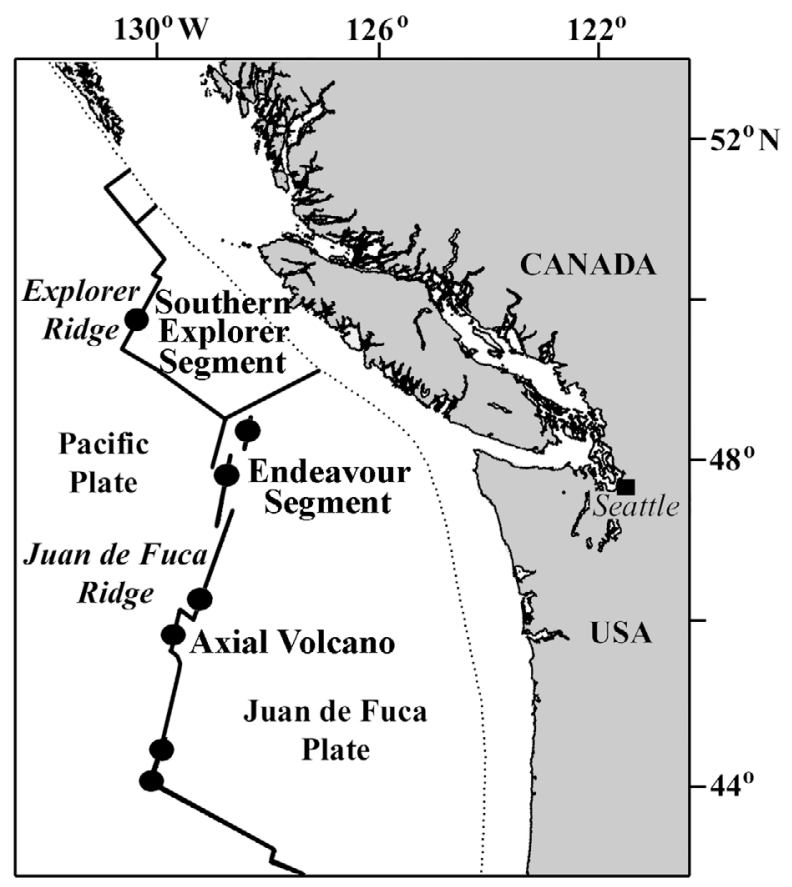

Fig. 2. Locations of Axial Volcano, Endeavour Segment (Juan de Fuca Ridge) and Southern Explorer Segment (Explorer Ridge), northeast Pacific Ocean. Black circles are active vent sites. Redrawn from Tunnicliffe et al. (1997)

\section{MATERIALS AND METHODS}

Sites and sampling. Hydrothermal vent fields were visited during summer months (May to September). Sites on the Juan de Fuca Ridge (1994 to 1995 and 2001 to 2003 ) were Axial Volcano $\left(45^{\circ} 56^{\prime} \mathrm{N}, 130^{\circ} 00^{\prime} \mathrm{W}\right.$; depth $1570 \mathrm{~m}$ ) and Endeavour Segment $\left(47^{\circ} 57^{\prime} \mathrm{N}\right.$, $129^{\circ} 06^{\prime} \mathrm{W}$; depth $\left.2220 \mathrm{~m}\right)$. On Explorer Ridge (2002), the study site was Southern Explorer Segment $\left(49^{\circ} 45^{\prime} \mathrm{N}, 129^{\circ} 42^{\prime} \mathrm{W}\right.$; depth $\left.1850 \mathrm{~m}\right)$ (Fig. 2). In situ manipulations and observations were conducted with the Canadian remotely operated vehicle, ROPOS. All studies were carried out at outflows diffusing through basalt or low sulphide mounds. A summary of the studies included in this paper are presented in Table 1.

Spatial patterns: Four observational studies relate spatial patterns of gastropod abundance, heat and distance from focused vent fluid flow (Table 1).

Within-vent abundance patterns: Spatial patterns of gastropod abundance were studied within $75 \mathrm{~cm}$ of fluid flows at 5 Axial Volcano vents, 2 Endeavour Segment vents and 3 Southern Explorer Segment vents in 2001 and 2002. Vents were selected based on the following criteria: (1) focused shimmering fluids were present; (2) tubeworms, known to change fluid flow patterns, were either small or absent; and (3) a single outflow was isolated by at least $3 \mathrm{~m}$ from other 
Table 1. Summary of studies undertaken in this work. Studies A(1) and A(2) related spatial patterns in gastropod abundance and heat to distance from focused vent flows. Studies A(3) and A(4) related spatial patterns in substratum occupation by gastropods to heat. Studies $\mathrm{B}(1)$ to $\mathrm{B}(3)$ tested whether in situ and in vitro behavioural responses relate to vent fluid parameters. Study type was observational (obs) or manipulative (man). Vent sites were Axial Volcano (Ax), Endeavour Segment (En) and Southern Explorer Ridge (Ex)

\begin{tabular}{|c|c|c|c|c|}
\hline Study approach & Type & Measurement & Parameters & Sites \\
\hline \multicolumn{5}{|l|}{ A. Spatial patterns } \\
\hline 1. In situ transect: $75 \mathrm{~cm}, \mathrm{n}=10$ & Obs & Gastropod relative abundance and density & $\begin{array}{l}\text { Distance from flow } \\
\text { Point temperatures }\end{array}$ & $\mathrm{Ax}, \mathrm{En}, \mathrm{Ex}$ \\
\hline 2. In situ transect: $65 \mathrm{~cm}, \mathrm{n}=2$ & Obs & Multi-day temperature time-series & Distance from flow & $\mathrm{Ax}, \mathrm{En}$ \\
\hline 3. In situ multi-vent survey, $\mathrm{n}=46$ & Obs & Gastropod presence/absence & Point temperature & $A x, E n, E x$ \\
\hline 4. In situ transect: $65 \mathrm{~cm}, \mathrm{n}=2$ & Obs & $\%$ gastropod cover & Temperature regime & $\mathrm{Ax}, \mathrm{En}$ \\
\hline \multicolumn{5}{|l|}{ B. Behavioural responses } \\
\hline 1. Fixed-area monitoring, $\mathrm{n}=1$ & Obs & $\begin{array}{l}\text { Time-series }(7 \mathrm{mo} \text { ) of \% gastropod } \\
\text { cover in images }\end{array}$ & Temperature regime & En \\
\hline 2. In situ choice, $\mathrm{n}=1$ & Man & End position in trackway after $77 \mathrm{~h}$ & $\begin{array}{l}\text { Distance from flow } \\
\text { Temperature range }\end{array}$ & Ax \\
\hline 3. In vitro choice, $\mathrm{n}=>2$ & Man & End position in gradient after 4 and $12 \mathrm{~h}$ & Temperature range & Ax \\
\hline
\end{tabular}

visible hydrothermal sources. We grouped samples into 3 distance categories from the focused fluid flow: in-vent, 0 to $25 \mathrm{~cm}$; near-vent, 26 to $50 \mathrm{~cm}$; and farvent, 51 to $75 \mathrm{~cm}$ (categorized by ROPOS pilots using laser spots at $10 \mathrm{~cm}$ apart). In-vent samples were typically immersed in shimmering water $(\mathrm{n}=10)$. Nearvent samples were at the edge of shimmering $(n=7)$ and, at far-vent locations, no shimmering was evident $(\mathrm{n}=10)$. Point measurements of maximum temperature were recorded for $\sim 5$ min for most sampled sites with a rugged transition joint probe (Adam's module thermistor, $\pm 1^{\circ} \mathrm{C}$ ).

Gastropods were collected from approximately $100 \mathrm{~cm}^{2}$ of substratum in each distance category using a suction sampler; removal efficiency was near 100\% as determined by close-up video. Samples were preserved in $7 \%$ formalin. All gastropods with greater than $1 \mathrm{~mm}$ shell length were identified and relative abundances were calculated. More than 100 gastropods occurred in all samples.

High quality video imagery with zoom included laser spots at $10 \mathrm{~cm}$ apart. A digital processing program (Image-Pro Plus ${ }^{\odot}$ 4.5) was used to quantify sample area when a distinct cleared patch was visible. It was possible to estimate density for 5 in-vent, 3 near-vent and 5 far-vent samples at Axial Volcano. Differences in species density between in- and far-vent were tested with a Monte Carlo Randomization (Manly 1991) routine; sample size was too low to include near-vent samples in this analysis.

Temperature variability: Temperatures were measured every 30 min along a transect running away from vent flow using digital temperature data loggers (DS1921L-F50 Thermochron iButton ${ }^{\odot}, \pm 0.5^{\circ} \mathrm{C}$ ) at Endea- vour Segment (15 d) and Axial Volcano (3 d). Deployment duration depended on the submersible dive schedule. We attached 5 loggers to the experimental apparatus described later (see 'Materials and methods' section 'Location preference') for the 2 deployments. For each logger, distance to the nearest fluid source was estimated from high resolution digital images. At the Endeavour location (distances 0, 10, 28 and $30 \mathrm{~cm}$ from flow), 2 fluid sources were visible, while a single fluid source was present at Axial $(5,20,35,50$, and $65 \mathrm{~cm}$ ). Because temperature loggers were embedded in epoxy resin for deep-sea use, a lag in temperature response was present. Response time was in the range of 0.25 to $1.25^{\circ} \mathrm{C} \mathrm{min}{ }^{-1}$ for temperature shifts of 1 to $25^{\circ} \mathrm{C}$.

Substratum occupation in relation to temperature: To determine the range of temperatures at which gastropods occur, we measured the maximum temperature over a 1 to 5 min period in venting fluids between 5 and $25^{\circ} \mathrm{C}$ at Axial Volcano $(\mathrm{n}=40)$, Endeavour Segment $(n=2)$ and Southern Explorer Segment $(n=4)$. During these temperature measurements, we collected video imagery of the substratum surrounding the custom-made platinum resistance temperature probe (Q396 Pt wirewound sensor, $\pm 0.5^{\circ} \mathrm{C}_{i}$ Logan Enterprises; courtesy of D. A. Butterfield). Presence or absence of any of the 3 gastropod species within a $1 \mathrm{~cm}$ radius of the probe was recorded.

Abundance in relation to temperature: Small-scale spatial changes in substratum use by the 3 gastropods were examined relative to temperature measurements using high resolution digital still images (Sony DSC $707 \mathrm{~F}$ ) around each of the 5 temperature loggers deployed in 2 transects (see 'Temperature variability' 


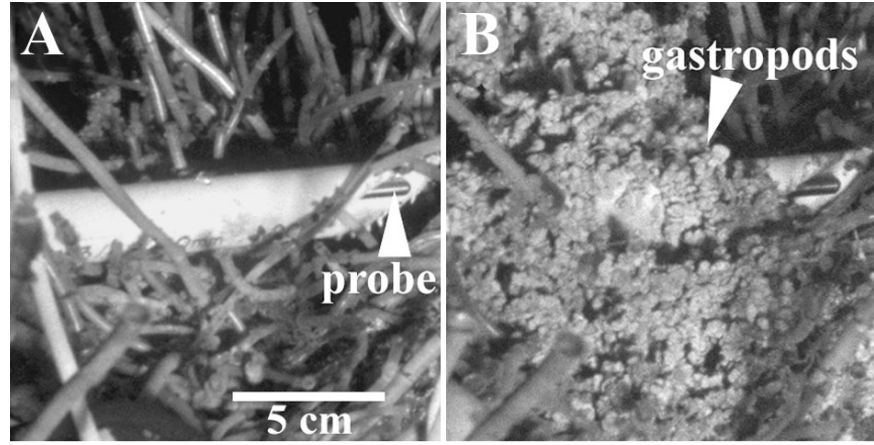

Fig. 3. Gastropod movement near a thermistor probe. Images are the same $225 \mathrm{~cm}^{2}$ area of larger colour high resolution images captured every $31 \mathrm{~h}$ by a time lapse camera $(\mathrm{n}=170)$. The substratum occupation by Lepetodrilus fucensis and Depressigyra globulus was quantified as the percent substratum covered by both species for each image. Measured distance is up to $15 \mathrm{~cm}$ from the thermistor probe. (A) The probe measured fluid temperature at one point (arrowhead) every $10 \mathrm{~min}$. Minimum gastropod presence $(1.5 \%$ substratum cover) occurred on October 8, 1994. (B) A gastropod mass, dominated by L. fucensis (arrowhead), reached maximum substratum cover (60\%) on February 21, 1995

section). The percentage of substratum covered by gastropods in a $10 \mathrm{~cm}^{2}$ area surrounding each temperature logger was measured (Image-Pro Plus ${ }^{\odot} 4.5$ ); animals down to $1 \mathrm{~mm}$ shell length were easily resolved. Mean temperature and one standard deviation were calculated for each record.

Behavioural responses: Studies were conducted over lengths of time that allowed individual gastropods to respond to fluid conditions (Table 1). In situ experiments tested for behavioural responses to changes in fluid heat and/or chemical variables. We assumed that measured temperature changes represented shifts in relative concentrations of vent fluids. Shipboard experiments identified behavioural responses to temperature.

Temporal changes in gastropod abundance related to temperature: A time-lapse camera (Photosea model 1200L) focused on a tubeworm bush at Easter Island $\left(47^{\circ} 56.9^{\prime} \mathrm{N}, 129^{\circ} 05.9^{\prime} \mathrm{W}\right)$, Endeavour Segment. An image was taken every $31 \mathrm{~h}$ as described in Martell et al. (2002). One sector of the image included a temperature probe (YSI 44000 deep-sea thermistor, $\pm 0.5^{\circ} \mathrm{C}$; courtesy of I. R. MacDonald) that recorded every $10 \mathrm{~min}$; data were averaged for the $31 \mathrm{~h}$ surrounding each image. To compare temporal changes in gastropod abundance to temperature, the percent of substratum occupied by the 3 gastropod species in the same $225 \mathrm{~cm}^{2}$ area (represented by Fig. 3A,B) around the temperature probe was measured in 170 high resolution colour images taken from July 17, 1994 to February 21, 1995.

Location preference: To determine if specific distances from a focused flow are preferred by each of the
3 species, we placed individuals in contained flowthrough tracks with one end positioned in venting fluid. The apparatus resembled a racetrack with 4 lanes, each being $75 \mathrm{~cm}$ long by $1.0 \mathrm{~cm}$ wide by $1.5 \mathrm{~cm}$ high; it was constructed with lexan sides and covered top and bottom with $2 \mathrm{~mm}$ plastic mesh (Fig. 4). The tracks were divided by gates into 5 regions at incremental distances from focused vent fluid: 0-15, 16-30, 31-45, 46-60, 61-75 cm (Fig. 4). The gates were left open during the deployment, allowing unrestricted movement within the track, until recovery when a bar was released causing the gates to close. Thus, numbers of animals in each region of the track could be determined accurately upon recovery of the apparatus. Temperatures were measured every $30 \mathrm{~min}$ at $15 \mathrm{~cm}$ intervals from the vent flow by attaching digital temperature data loggers (see 'Temperature variability') to the outside of the experimental apparatus (Fig. 4).

Mrk 33 Vent (Embley et al. 1999) on Axial Volcano was selected because fluid emerges from a discrete crack in basalt (verified with temperature measures prior to the deployment of the experiment). Animals within $50 \mathrm{~cm}$ of the crack were collected by low power suction and brought immediately to the surface. Three species-specific tracks contained 100 individuals of Lepetodrilus fucensis, Depressigyra globulus and Provanna variabilis; in the 4 th track we pooled 100 individuals of each species. Animals were stored in $4^{\circ} \mathrm{C}$ sea water for $6 \mathrm{~h}$ until their return to the seafloor. During descent, all animals were jostled to one end of the apparatus. We positioned this end away from Mrk 33 Vent in $3^{\circ} \mathrm{C}$ fluid. We returned after an $85 \mathrm{~h}$ acclimation period (determined by the research dive schedule) and turned the apparatus $180^{\circ}$. The animals were left to disperse for $77 \mathrm{~h}$, after which we closed the gates and recovered the apparatus. Due to weather constraints, we were unable to replicate this experiment.

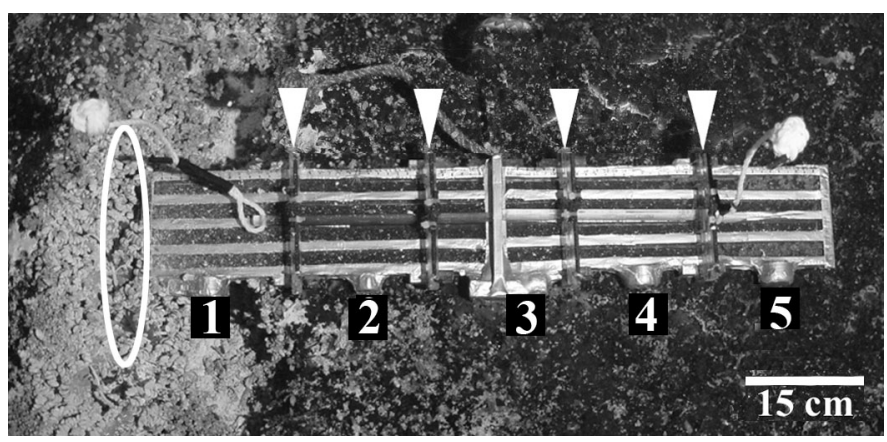

Fig. 4. Experimental apparatus deployed at Mrk 33 Vent (Axial Volcano) to determine if 3 gastropod species move to specific distances from a focused flow (see 'Location preference'). White arrowheads indicate the positions of spring-close gates. The white oval marks the vent flow. Numbers 1 to 5 show the position of digital temperature data loggers (see 'Temperature variability') attached to the outside of the apparatus 
In vitro temperature response: To determine if these gastropod species respond to gradients in temperature, we established shipboard experimental chambers with spatial gradients (in 2003). A pressurized experimental vessel with a horizontal temperature gradient was used (pilot studies identified geotaxis in vertical chambers as a confounding factor). Animals were placed in a chamber made from an anodized aluminum block with free access along a groove $20 \mathrm{~cm}$ long by $1 \mathrm{~cm}$ wide by $1.5 \mathrm{~cm}$ high. A polycarbonate window allowed viewing of the animals under pressure. Filtered seawater was pumped into the chamber inlet with a Beckman 110B high pressure liquid chromatography pump at a rate of $1 \mathrm{ml} \mathrm{min}{ }^{-1}$. Pressure in the chamber was maintained at $13789 \mathrm{kPa}$ (2000 psi) by a Whitey backpressure regulator on the chamber outflow tubing. A temperature gradient was created by placing the chamber in a waterbath cooled with ice at one end and heated with a submersible heating element at the opposite end. Every $30 \mathrm{~min}$, we measured the temperature gradient with a digital thermometer probe (VWR, $\pm 0.2^{\circ} \mathrm{C}$ ) placed in holes spaced at intervals of 1 to $2.5 \mathrm{~cm}$ along the aluminum block. We extrapolated temperature for intermediate positions based on a linear relationship between temperature and distance. Block temperature occasionally fluctuated by a maximum of $1{ }^{\circ} \mathrm{C}$ due to melting and replacement of ice. Preliminary trials at surface pressure showed that fluid temperature in the chamber responded to a $5^{\circ} \mathrm{C}$ change in the aluminum block in less than $5 \mathrm{~min}$.

Gastropod collections were made at Axial Volcano $(1580 \mathrm{~m})$ because a notable decrease in moribundity at surface pressure occurred compared to Endeavour $(2220 \mathrm{~m})$. Each trial consisted of 30 individuals of each species (animals ranged between 3 and $7 \mathrm{~mm}$ shell length); animals in different trials originated from different vents. Immediately after collection, animals were acclimated at pressure for $4 \mathrm{~h}$ at $4^{\circ} \mathrm{C}$. We recorded the position of each individual in control and temperature gradient treatments after 4 (6 trials) and $12 \mathrm{~h}$ ( 2 trials). In controls temperature was maintained at $8^{\circ} \mathrm{C}$ (this temperature was selected because Lepetodrilus fucensis did not move at $4^{\circ} \mathrm{C}$ after $4 \mathrm{~h}$, but was mobile at $8^{\circ} \mathrm{C}$ ). Two temperature treatments were run: (1) $4 \mathrm{~h}$ in a steep (4 to $30^{\circ} \mathrm{C}$ ) gradient, and (2) $12 \mathrm{~h}$ in a shallow (4 to $18^{\circ} \mathrm{C}$ ) gradient. Prior to the start of the gradient experiments, animals were positioned in one end of the chamber. This end was subsequently heated to create the gradient over $30 \mathrm{~min}$ with a maximum temperature increase of $1^{\circ} \mathrm{C} \mathrm{min}^{-1}$. All individuals in pressurized experiments remained active.

The species-specific distributions between trials where animals were collected from different vents were similar ( $\mathrm{p}>0.3$, Kruskal-Wallis $H$-test, $\chi^{2}<2$ ). Thus, the data sets from each trial for each species were pooled

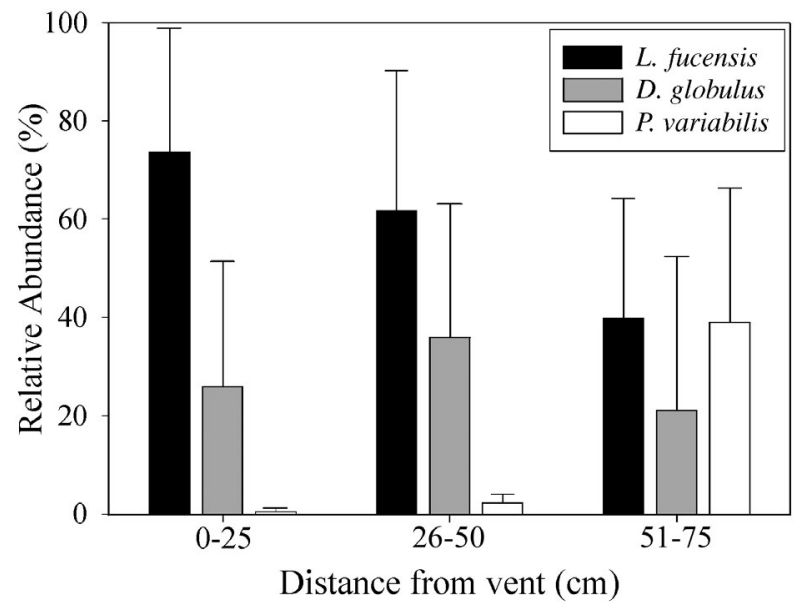

Fig. 5. Lepetodrilus fucensis, Depressigyra globulus and Provanna variabilis. Relative abundance (mean +1 SD) with distance from focused vent flows for collections in-vent at 0 to $25 \mathrm{~cm}\left(\mathrm{n}=10,5\right.$ to $\left.15^{\circ} \mathrm{C}\right)$, near-vent at 26 to $50 \mathrm{~cm}(\mathrm{n}=7$, 3 to $\left.5^{\circ} \mathrm{C}\right)$ and far-vent at 51 to $75 \mathrm{~cm}\left(\mathrm{n}=10,<3^{\circ} \mathrm{C}\right)$. L. fucensis is the dominant species. The relative abundances of $L$. fucensis and D. globulus are greatest in- and near-vent, while $P$. variabilis is relatively most abundant far-vent

and potential differences due to site of origin were ignored to examine differences between treatments and species. Standard box plot diagrams represent these pooled distributions. SPSS 11.0 was used to test for significant differences in the distributions between species using a Kruskal-Wallis $H$-test for independent samples. A post-hoc Mann-Whitney $U$-test for 2 independent samples identified significantly different data sets.

\section{RESULTS}

\section{Spatial patterns}

\section{Within-vent abundance patterns}

Although most vents do not fit the sample location requirements we imposed, isolated focused flow occasionally did create 'islands' on the substratum for use as model sites (e.g. Fig. 1A). The 3 gastropod species occurred at all sampling locations (Fig. 1B). However, the relative abundance of each species changed with distance from vent (Fig. 5). Lepetodrilus fucensis was numerically dominant in-vent (0 to $25 \mathrm{~cm}$ ), with a relative abundance of $75 \%$; it decreased to $60 \%$ near-vent (26 to $50 \mathrm{~cm}$ ) and to $40 \%$ far-vent $(51$ to $75 \mathrm{~cm})$. The relative abundance of Depressigyra globulus ranged between 21 and $36 \%$ in all distance categories. Provanna variabilis was relatively more abundant far-vent $(40 \%)$ than in- and near-vent $(1 \%)$. 

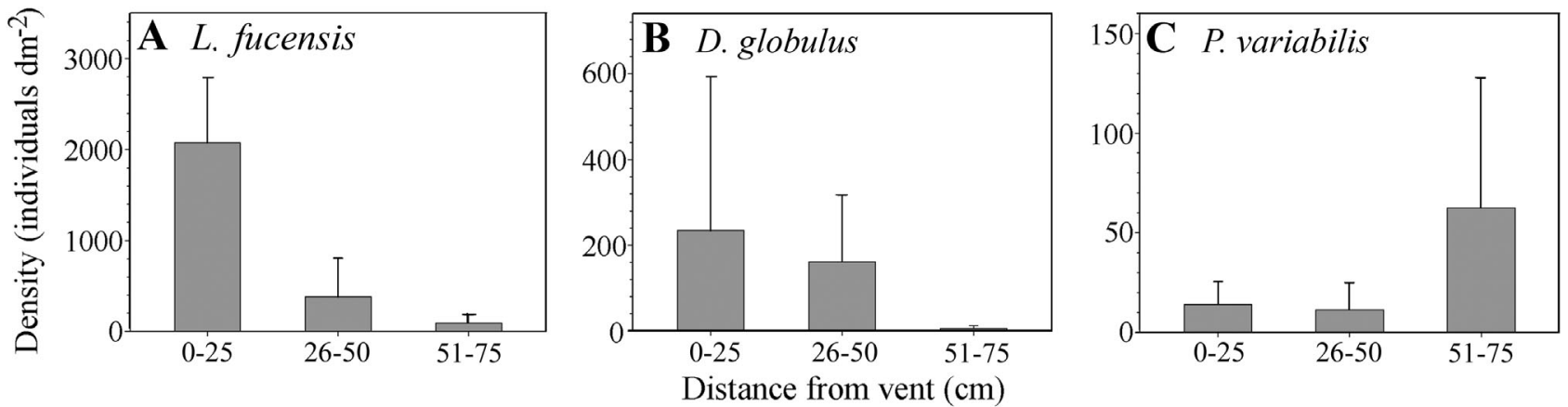

Fig. 6. Lepetodrilus fucensis, Depressigyra globulus and Provanna variabilis. Density (mean +1 SD) with distance from focused flows for collections in-vent at 0 to $25 \mathrm{~cm}\left(\mathrm{n}=5,5\right.$ to $\left.15^{\circ} \mathrm{C}\right)$, near-vent at 26 to $50 \mathrm{~cm}\left(\mathrm{n}=3,3\right.$ to $\left.5^{\circ} \mathrm{C}\right)$ and far-vent at 51 to $75 \mathrm{~cm}$ $\left(\mathrm{n}=5,<3^{\circ} \mathrm{C}\right.$ ). $Y$-axes differ by an order of magnitude. L. fucensis and $D$. globulus densities are each significantly greater $(\mathrm{p}<0.001$; Monte Carlo Randomization Test) in- versus far-vent. $P$. variabilis displays the reverse pattern $(\mathrm{p}<0.05)$

The species density in each distance category provides information on habitat use (Fig. 6). Lepetodrilus fucensis was most abundant (mean of 2100 ind. $\mathrm{dm}^{-2}$ ) in-vent and decreased by an order of magnitude through near-vent (400 ind. $\mathrm{dm}^{-2}$ ) to far-vent (90 ind. $\mathrm{dm}^{-2}$ ). Depressigyra globulus had similar densities inand near-vent (means of 240 and 160 ind $\mathrm{dm}^{-2}$, respectively) and decreased to 60 ind. $\mathrm{dm}^{-2}$ at far-vent locations. L. fucensis and D. globulus reached maximum densities of 2900 and 950 ind. $\mathrm{dm}^{-2}$ (respectively) invent where their mean densities were significantly greater than far-vent ( $\mathrm{p}<0.001$, Monte Carlo Randomization). Provanna variabilis displayed the reverse trend. Its mean density far-vent (60 ind. $\mathrm{dm}^{-2}$ ) was significantly greater than in-vent $\left(10\right.$ ind. $\left.\mathrm{dm}^{-2}\right)(\mathrm{p}<0.05$, Monte Carlo Randomization). The maximum density of $P$. variabilis was 200 ind. $\mathrm{dm}^{-2}$ in a far-vent sample.
Temperature variability

Point temperatures of fluids where animals were collected from in-, near- and far-vent locations ranged from 5 to $15^{\circ} \mathrm{C}, 3$ to $5^{\circ} \mathrm{C}$ and $<3^{\circ} \mathrm{C}$, respectively. We also recorded temperatures every $30 \mathrm{~min}$ with temperature loggers for several days along two $75 \mathrm{~cm}$ transects from focused flow. In-vent temperatures were highly variable: mean $\pm 1 \mathrm{SD}$, minimum, and maximum at the Endeavour location for 3 in-vent sites were $(0 \mathrm{~cm}$ from flow $\left.=12.3 \pm 2.0,7.5,15.0^{\circ} \mathrm{C}\right),(0 \mathrm{~cm}=7.3 \pm 1.5$, $\left.5.0,10.5^{\circ} \mathrm{C}\right)$ and $\left(10 \mathrm{~cm}=6.0 \pm 1.8,3.0,10.0^{\circ} \mathrm{C}\right)$. Two invent sites at Axial were monitored: $(5 \mathrm{~cm}$ from flow $=$ $\left.8.1 \pm 2.3,3.5,12.5^{\circ} \mathrm{C}\right)$ and $\left(20 \mathrm{~cm}=5.3 \pm 1.6,3.0,8.5^{\circ} \mathrm{C}\right)$. In comparison, near- and far-vent locations were relatively stable (Fig. 7). For example, loggers placed 35 (near) and $65 \mathrm{~cm}$ (far) from flow at Axial returned
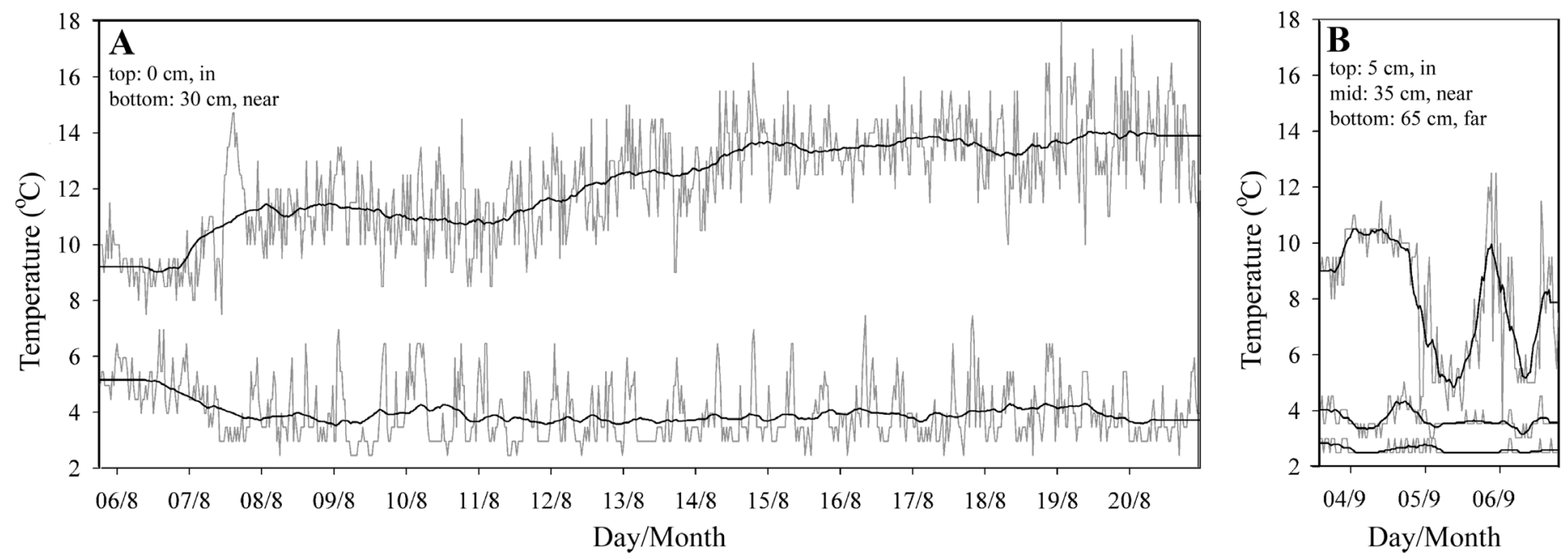

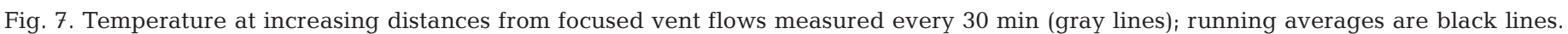

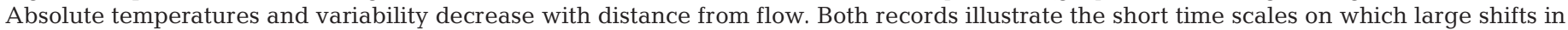

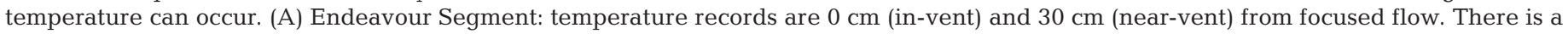

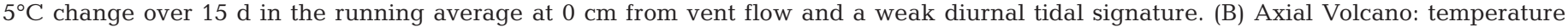

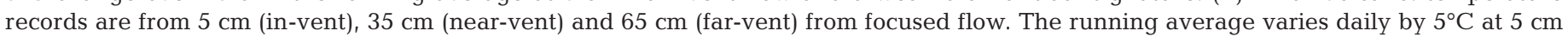


the following mean $\pm 1 \mathrm{SD}$, minimum, and maximum (respectively): $\left(3.6 \pm 0.4,3.0,5.0^{\circ} \mathrm{C}\right)$ and $(2.6 \pm 0.2,2.5$, $3.0^{\circ} \mathrm{C}$ ). The temporal temperature records indicate high variability at in-vent locations at various time scales (Fig. 7). In-vent temperature changes of 3 (Endeavour) and $5^{\circ} \mathrm{C}$ (Axial) in 30 min occurred. In-vent animals were also subject to longer term variability than near- or far-vent locations. Diurnal variations and a $5^{\circ} \mathrm{C}$ warming trend were evident in the Endeavour in-vent record (Fig. $7 \mathrm{~A}$ ). A $5^{\circ} \mathrm{C}$ daily change in the running average temperature at Axial was also recorded (Fig. 7B).

Substratum occupation in relation to temperature

Point temperature measurements coupled with images from numerous vents documented the range of fluid conditions in which the 3 gastropod species occur (Fig. 8). Lepetodrilus fucensis and Depressigyra globulus were visible at all 21 locations below $14^{\circ} \mathrm{C}$ and at 8 locations in 14 to $17^{\circ} \mathrm{C}$ fluids. The 3 species were absent from all 14 locations surveyed where maximum fluid temperatures reached $18^{\circ} \mathrm{C}$ or higher. These gastropods were also absent from another 3 locations with maximum fluid temperatures between 14 and $17^{\circ} \mathrm{C}$. Provanna variabilis was only rarely distinguishable among the other 2 species in video images. Therefore, the upper temperature limit for $P$. variabilis may be less than the other 2 species.

Abundance in relation to temperature

Loggers recorded mean temperatures between 3 and $12^{\circ} \mathrm{C}$ at Endeavour and Axial (Fig. 9). Lepetodrilus

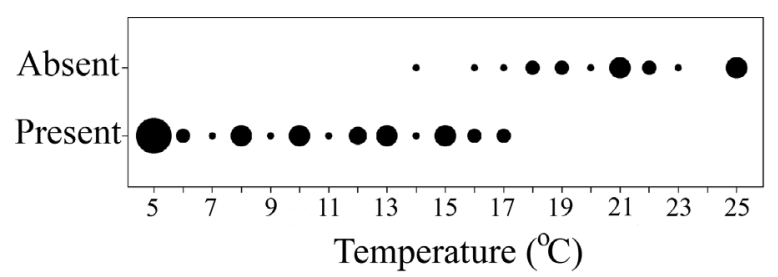

Fig. 8. Observations of gastropod presence relative to point temperature measurements over a 5 to $25^{\circ} \mathrm{C}$ range. Circle size represents number of sites (largest $=5$, smallest $=1$ ) with gastropods present or absent from the substratum within a $1 \mathrm{~cm}$ radius of the temperature probe. Sites from Axial Volcano ( $\mathrm{n}=$ $40)$, Endeavour Segment $(\mathrm{n}=2)$ and Southern Explorer Segment $(\mathrm{n}=4)$ were surveyed. Gastropods were visible at all locations below $14^{\circ} \mathrm{C}(\mathrm{n}=21)$ and at 8 locations in 14 to $17^{\circ} \mathrm{C}$ fluids. Gastropods were absent at all locations $(n=14)$ in fluid temperatures of $18^{\circ} \mathrm{C}$ or higher and from another 3 locations with maximum fluid temperatures between 14 and $17^{\circ} \mathrm{C}$ fucensis was dominant in the images, Depressigyra globulus was always visible and Provanna variabilis was sporadically visible. Because we could not determine the percent substratum cover by species from images, our values are a combined estimate for all 3 species. Substratum coverage in the $10 \mathrm{~cm}^{2}$ areas surrounding the loggers increased at higher temperatures. L. fucensis was visible in images on $100 \%$ of the available substratum and formed stacks when temperatures ranged between $8.1 \pm 2.3$ and $12.3 \pm 2.0^{\circ} \mathrm{C}_{i}$ coverage dropped below $10 \%$ in temperatures below $4.0 \pm 0.9^{\circ} \mathrm{C}$.

\section{Behavioural responses}

Temporal changes in gastropod abundance versus temperature

Early images from the time-lapse camera series showed a mass of gastropods in the area immediately surrounding the thermistor (Fig. 3). The gastropod mass disappeared then reappeared in the same area over $220 \mathrm{~d}$. These temporal changes in the percent substratum cover by the gastropods correspond to changes in the temperature record (Fig. 10A). However, the temperature range recorded in this study (2 to $5^{\circ} \mathrm{C}$ ) represents the low-end of habitat temperatures for these gastropods. Although the thermistor probably does not record the actual temperature within the gas-

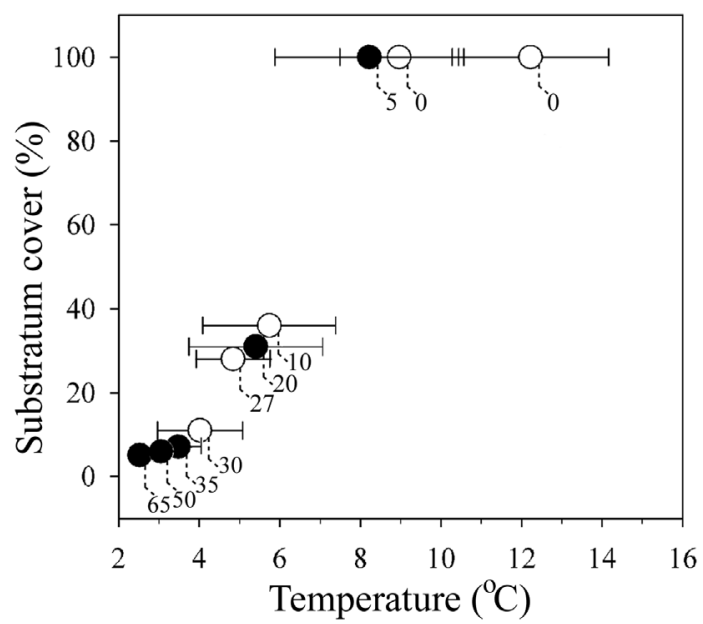

Fig. 9. Relationship between gastropod substratum cover (\%) and temperature (mean $\pm 1 \mathrm{SD}$ ) along 2 transects at Endeavour Segment (O) and Axial Volcano (•). Numbers indicate distance $(\mathrm{cm})$ from focused flow. Substratum cover was quantified from high resolution digital images in a $10 \mathrm{~cm}^{2}$ square area adjacent to each temperature logger. Mean temperatures were calculated from 30 min recordings over $15 \mathrm{~d}$ at Endeavour and $3 \mathrm{~d}$ at Axial. Substratum cover is $100 \%$ at temperatures above $8^{\circ} \mathrm{C}$ and approaches zero when fluid temperatures are near ambient $\left(2^{\circ} \mathrm{C}\right)$. See Fig. 7 for examples of complete temperature records 


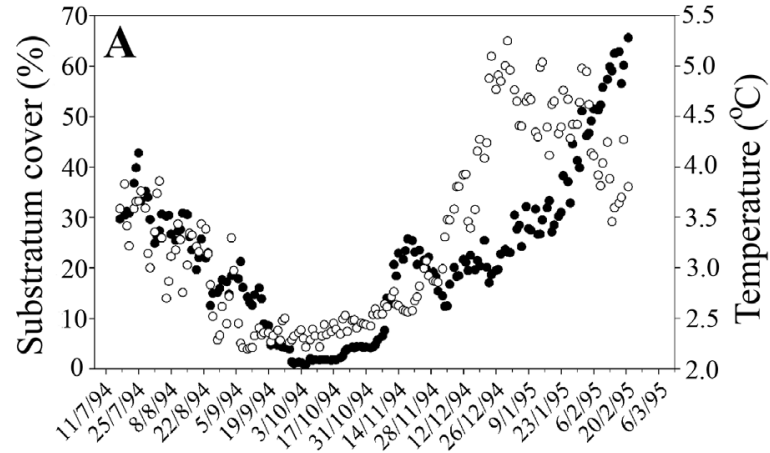

Date

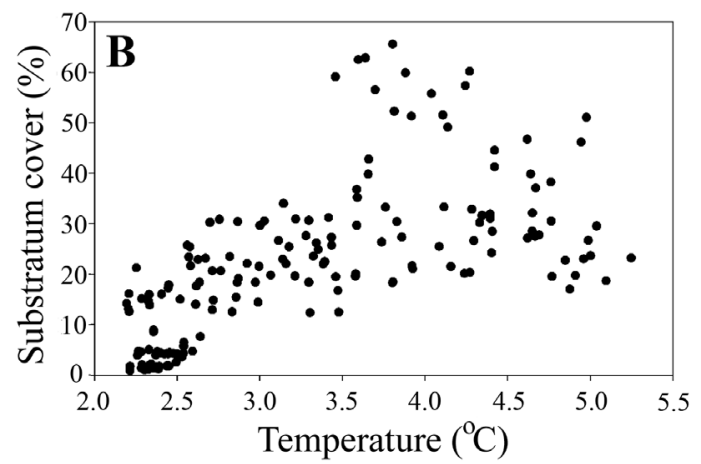

Fig. 10. Changes in gastropod abundances in a tubeworm aggregation over 7 mo using in time-lapse camera images at Endeavour Segment. Image interval was $31 \mathrm{~h}(\mathrm{n}=170)$. See Fig. 3 for further details. (A) Gastropod substratum cover and mean fluid temperatures show similar trends with time. (B) Gastropod substratum cover and mean temperature are significantly correlated $(\mathrm{p}<0.01$, Spearman's rho $=0.73, \mathrm{df}=$ 168). Substratum cover approaches zero when fluid temperatures are near ambient $\left(2^{\circ} \mathrm{C}\right)$

tropod mass, percent cover and temperature are significantly correlated ( $\mathrm{p}<0.01$, Spearman's Rank Correlation $=0.71$, df $=168$ ) (Fig. 10B). Substratum cover ranged from 0 to $20 \%$ when fluid temperatures were below $2.5^{\circ} \mathrm{C}$ (Figs. 3A \& 10B). However, the maximum values for gastropod substratum cover (66\%) (Figs. 3B $\& 10 \mathrm{~B})$ do not correspond with maximum temperatures $\left(5^{\circ} \mathrm{C}\right)$.

\section{Location preference}

Lepetodrilus fucensis was less mobile than the other 2 species in the trackway. After the acclimation period (85 h), a clump of L. fucensis was visible in their starting position at one end of the track in $3^{\circ} \mathrm{C}$ fluids while the other 2 species were more dispersed. Consequently, when the trackway was turned, many $L$. fucensis started the experiment within $10 \mathrm{~cm}$ from the vent (see 'Materials and methods'). When we returned after the experimental duration $(77 \mathrm{~h})$, camera images revealed that these $L$. fucensis had moved. Nearly all L. fucensis and Depressigyra globulus were found within $30 \mathrm{~cm}$ of flow (Fig. 11). Video showed that this area was bathed in vent fluid with temperature values of $8.1 \pm 2.3^{\circ} \mathrm{C}$ at $5 \mathrm{~cm}$ and $5.3 \pm 1.6^{\circ} \mathrm{C}$ at $20 \mathrm{~cm}$ over $3 \mathrm{~d}$ (Fig. 11 inset). Provanna variabilis occurred in similar numbers in all distance categories of the track in fluids with temperatures ranging from $8.1 \pm 2.3$ to $2.6 \pm 0.2^{\circ} \mathrm{C}$ (Fig. 11 inset). The lane with all 3 species combined returned comparable results to the single species lanes (Fig. 11).

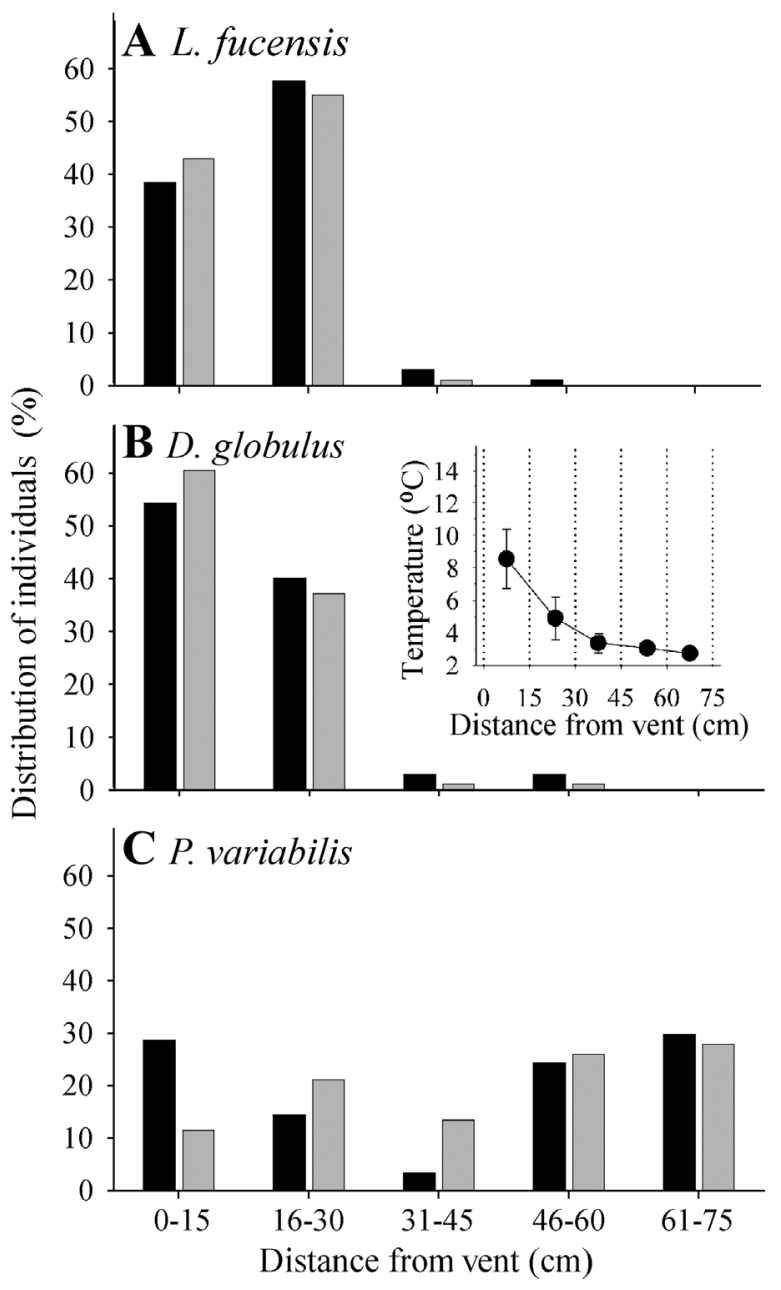

Fig. 11. Lepetodrilus fucensis, Depressigyra globulus and Provanna variabilis. Final positions after $77 \mathrm{~h}$ along a $75 \mathrm{~cm}$ trackway oriented with one end in vent flow to create a gradient in vent fluid concentration (see Fig. 4). A single species lane contained 100 individuals from 1 species (gray bars); the mixed species lane contained 100 individuals from each species (black bars). The inset shows the relationship between temperature (mean $\pm 1 \mathrm{SD}$ ) and distance from focused vent fluids (see Fig. 7B for examples of complete temperature records). (A) L. fucensis cluster within $30 \mathrm{~cm}$ of the vent where mean temperatures are 5 to $8^{\circ} \mathrm{C}$. (B) D. globulus cluster within $30 \mathrm{~cm}$ of the vent where mean temperatures are 5 to $8^{\circ} \mathrm{C}$. (C) $P$. variabilis are uniformly distributed with distance from vent at 3 to $8^{\circ} \mathrm{C}$ 
In vitro temperature response

Temperature had a significant influence on the distributions of all 3 gastropod species in both 4 and $12 \mathrm{~h}$ trials ( $\mathrm{p}<0.001$, Mann-Whitney $U$-test, $Z<-7.5$ ). There were no differences among the control distributions for all 3 species ( $\mathrm{p}>0.7$, Kruskal-Wallis $H$-test, $\left.\chi^{2}<0.5\right)$; individuals in the controls were evenly dispersed. Lepetodrilus fucensis and Depressigyra globulus in the $4 \mathrm{~h}\left(4\right.$ to $30^{\circ} \mathrm{C}$, steep gradient) and the $12 \mathrm{~h}$ (4 to $18^{\circ} \mathrm{C}$, shallow gradient) temperature treatments occupied similar temperature ranges (Fig. 12). In the $4 \mathrm{~h}$ trial with a steep temperature gradient, $90 \%$ of $L$. fucensis individuals were between 5 and $13^{\circ} \mathrm{C}$, while D. globulus were between 5 and $15^{\circ} \mathrm{C}$. The distributions of both species were skewed toward lower temperatures. In comparison, $90 \%$ of individuals for both species were between 5 and $13^{\circ} \mathrm{C}$ in the $12 \mathrm{~h}$ trial and were symmetrical around the mean. For Provanna variabilis, the distributions were similar for 4 and $12 \mathrm{~h}$ trials; $90 \%$ of $P$. variabilis individuals occurred between 4 and $11^{\circ} \mathrm{C}$ and the distribution was skewed toward lower temperatures (50\% of animals between 4 and $5^{\circ} \mathrm{C}$ ) (Fig. 12). Individuals of $P$. variabilis were distributed to significantly ( $p<0.001$, Mann-Whitney $U$-test, $Z<-5.5$ ) lower temperatures than $L$. fucensis and $D$. globulus in both the 4 and $12 \mathrm{~h}$ trials. We observed that D. globulus and $P$. variabilis dispersed rapidly at $4^{\circ} \mathrm{C}$, while $L$. fucensis did not. However, all 3 species moved in chambers at $8^{\circ} \mathrm{C}$.

\section{DISCUSSION}

\section{Spatial patterns}

Three gastropod species at Juan de Fuca vents showed small-scale patterns in abundance. Lepetodrilus fucensis displayed the most marked gradient with distance from focused vent flows, and had higher densities than Depressigyra globulus and Provanna variabilis in all in-vent samples. The stacking behaviour of L. fucensis (Fig. 1A) probably allows increased access to suspended food particulates when population densities are high (A. Bates pers. obs.). D. globulus, also most abundant in-vent, may exploit interstitial spaces by virtue of its small size. $P$. variabilis was relatively less abundant than the other 2 species and its density increased from in- to far-vent. Its occupation of farvent habitats might explain results from studies that report a unique carbon isotope signature for $P$. variabilis (Levesque 2003).

The thermal regime changed over spatial scales that correspond with observed gastropod density gradients. In-vent animals experienced higher mean tem-

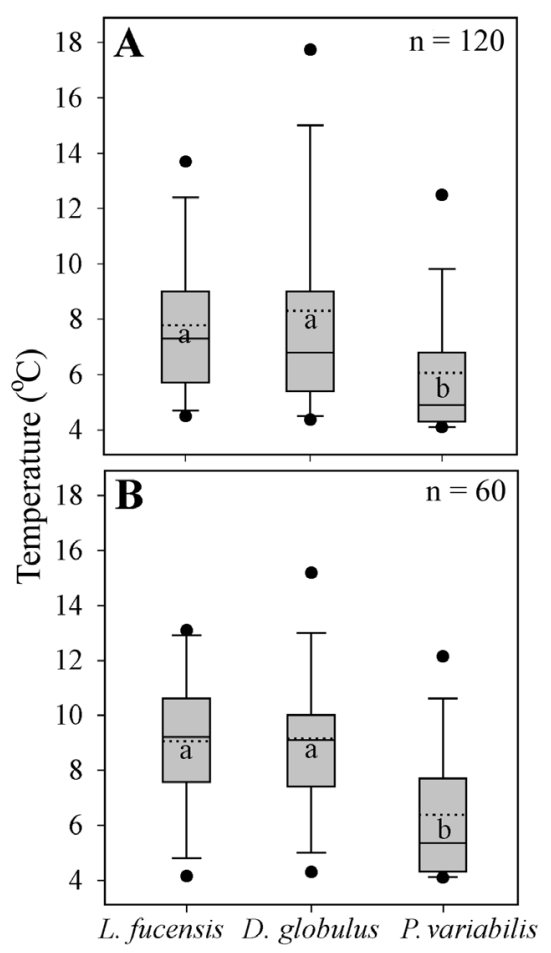

Fig. 12. Lepetodrilus fucensis, Depressigyra globulus and Provanna variabilis. Behavioural responses to temperature gradients in pressurized (13 $789 \mathrm{kPa})$ horizontal chambers; positions were recorded after $4 \mathrm{~h}$ (6 trials) and $12 \mathrm{~h}$ ( 2 trials). Box plots present 5 th, 25 th, 50 th, 75 th, 95 th percentiles; the dotted line is mean. Means with dissimilar letters differ significantly from each other ( $p<0.01$; Mann-Whitney $U$-test). Significant differences in responses exist both among species and compared to controls. $\mathrm{n}=$ individuals per species. (A) Distributions in a 4 to $30^{\circ} \mathrm{C}$ temperature gradient after $4 \mathrm{~h}$; species-specific distributions in (A) are similar to (B). (B) Distributions in a 4 to $18^{\circ} \mathrm{C}$ temperature gradient after $12 \mathrm{~h}$. Ninety \% of L. fucensis and $D$. globulus occupy 5 to $13^{\circ} \mathrm{C}_{i} 90 \%$ P. variabilis occupy significantly cooler temperatures from 4 to $10^{\circ} \mathrm{C}$

peratures and variability at both short and long timescales while animals distant from flows are in relatively stable, low temperature fluids. Diurnal variation in our in-vent temperature record is likely tidally driven. Tivey et al. (2002) show that fluid mixing is affected by tidal and bottom currents over hours to days. We also observed a $5^{\circ} \mathrm{C}$ warming trend over $15 \mathrm{~d}$ at an Endeavour in-vent location. The cause is unknown but other studies record spikes in fluid heat after earthquake swarms; fluids at Endeavour Segment vents increased 4 to $11^{\circ} \mathrm{C}$, and $\pm 5^{\circ} \mathrm{C}$ temperature oscillations were present for 8 to $12 \mathrm{~d}$ (Johnson et al. 2000).

Change in thermal regime indicates differences in environmental conditions. Butterfield et al. (2004) show that temperature in a Juan de Fuca vent field is a good proxy for chemical mixing especially within one vent. Currently the assessment of the physico- 
chemical status of habitats both at and beyond the fluid exit point is challenged by lack of sufficient data. Therefore, extrapolation to other fluid parameters should be done cautiously. Future studies aiming to experimentally determine the influence of additional environmental parameters (e.g. hydrogen sulphide concentration) in habitat selection by these species are important.

Substratum occupation and coverage by the 3 gastropod species also relates to heat. All species were absent above $17^{\circ} \mathrm{C}$ and presence was unpredictable between 14 and $17^{\circ} \mathrm{C}$, suggesting an in situ thermal limit for these species within these temperatures. This uncertainty range likely reflects the difficulty in estimating a thermal limit by recording point temperature measurements in highly variable conditions. Further, the percent cover by Lepetodrilus fucensis and Depressigyra globulus at decimeter scales corresponded to temperature differences; above mean temperatures of $8^{\circ} \mathrm{C}$, gastropods occupy all available substratum and L. fucensis begins stacking. These observations are consistent with the hypothesis that heat and/or vent fluid chemistry is important to habitat selection by these 3 species.

\section{Responses to vent fluids}

Lepetodrilus fucensis and Depressigyra globulus actively seek specific conditions. When placed in cold temperatures, they selected warmer vent flows and a mass of gastropods grew in size as temperature increased. Substrata bathed in vent fluids probably offer the greatest food availability for animals that graze and suspension feed, as these fluids deliver subsurface bacteria, particulates and reduced metals for further surface bacterial growth (Jannasch 1995, Giere et al. 2003). It is also likely that the association between L. fucensis and a chemoautotrophic symbiont (de Burgh $\&$ Singla 1984, Fox et al. 2002) requires access to dissolved sulphide and oxygen (A. Bates unpubl. data). Although maximum substratum occupation by these species did not co-occur with maximum temperatures in our time-lapse images, the dense stacks of limpets visible below the thermistor may have re-directed flow around the probe during the time of maximum coverage, thus reducing measured temperature.

Lepetodrilus fucensis and Depressigyra globulus selected locations in focused vent fluids when interspecific interactions and other habitat cues were eliminated experimentally. This result suggests that the relative scarcity of $L$. fucensis and D. globulus in farvent habitats is because these species prefer habitats in vent flows. In contrast, Provanna variabilis was evenly distributed with distance from focused vent fluids. The process giving rise to relatively higher densities of this species far-vent is probably not a behavioural preference for specific fluid parameters.

Although manipulation of experimental animals can influence behavioural responses (e.g. Chapman 1999, 2000), the results from the location preference experiment are consistent with the time-series observations of animals in their natural environment. Shock due to change in pressure may also have influenced behaviour. Although Depressigyra globulus and Provanna variabilis were mobile when returned to the seafloor, Lepetodrilus fucensis was less active. However, the acclimation period was conducted at $3^{\circ} \mathrm{C}$ and shipboard observations suggest difference in mobility is more likely due to cold temperatures than to pressure shock.

\section{Responses to temperature}

In the shipboard gradient experiments, the temperature ranges chosen by animals collected from different vents were similar. Because access inside experimental chambers was unimpeded, we infer that these temperature zones represent their preferences. Animals in gradient treatments were exposed to temperatures at which they are absent in situ (up to $30^{\circ} \mathrm{C}$ ) and individuals moved away from the high heat. Active selection of specific temperatures indicates preferred ranges (Voss et al. 2001). Also, the range of temperatures occupied by each species reflects results from the location preference experiment.

Temperature is probably a cue by which Lepetodrilus fucensis and Depressigyra globulus locate preferred vent flows. They selected temperatures ( 5 to $13^{\circ} \mathrm{C}$ ) typical of in-vent habitats where they are found at their highest densities. In comparison, Provanna variabilis preferred significantly cooler temperatures. Although $P$. variabilis is most abundant out of vent flows from 3 to $4^{\circ} \mathrm{C}$, it did not avoid warmer fluids. Thus, the relatively high far-vent densities of $P$. variabilis are probably not driven by a behavioural response to temperature.

Each species selected a wide range in temperatures (Lepetodrilus fucensis and Depressigyra globulus: 5 to $13^{\circ} \mathrm{C}$; Provanna variabilis: 4 to $11^{\circ} \mathrm{C}$ ). These ranges likely reflect the extreme thermal variability of vent flows in space and time. Point measures of different vents ranged between 4 and $17^{\circ} \mathrm{C}$. Fluctuations up to $5^{\circ} \mathrm{C}$ in $30 \mathrm{~min}$ were evident in-vent; the magnitude of these fluctuations was underestimated due to a delay in logger response. As D. globulus has a higher temperature tolerance than L. fucensis (Lee 2003) and moves more quickly, it may be able to better tolerate short-term exposures to higher fluid temperatures than $L$. fucensis. The greater tolerance and mobility of $D$. globulus may explain why several individuals ven- 
tured for short time periods ( $<5 \mathrm{~min}$ ) into fluids up to $20^{\circ} \mathrm{C}$ in our gradient experiments, while L. fucensis avoided these temperatures.

Our experiments also indicate that these 3 species have moderate upper thermal limits, around $13^{\circ} \mathrm{C}$ for Lepetodrilus fucensis and Depressigyra globulus and $11^{\circ} \mathrm{C}$ for Provanna variabilis. These temperatures are lower than in situ thermal limits that ranged from 14 to $17^{\circ} \mathrm{C}$; this difference is likely a consequence of the heat stability in the shipboard experiments relative to in situ conditions. These species can survive only short exposure to temperatures over $30^{\circ} \mathrm{C}$ (Lee 2003). Most individuals became inactive in our study after $72 \mathrm{~h}$ at $17^{\circ} \mathrm{C}$. In the fluctuating vent habitat, gastropods may occupy positions that leave a margin of safety from heat exposure that exceeds their physiological tolerances. A next step is to examine the response of these species to fluctuating temperatures.

Temperature responses may minimize exposure to a combination of environmental stresses, as is found for shoreline gastropods (Underwood 1979, McMahon 1990). Fluids up to $15^{\circ} \mathrm{C}$ contain hydrogen sulphide concentrations well below $500 \mu \mathrm{M}$ (e.g. Johnson et al. 1986, Marcus et al. 2003, Butterfield et al. 2004); however, toxicity and duration of anoxia increases with temperature (Johnson et al. 1986, 1988). Extreme fluctuations in these variables may also act synergistically to impose limits on these 3 gastropods, which may not be able to adapt to the variability in higher temperature flows. Physiological flexibility in extreme environments is likely key to surviving high variability (Bergquist et al. 2004, Peck 2004).

Alternatively, these gastropods may occupy habitats in moderate temperature fluids as a result of interactions with other species. If so, their preferred temperatures could simply reflect adaptation to the thermal regime presented by these habitats. For example, (Marcus et al. 2003) report that, over a range of sulphide-to-heat ratios, the combined relative abundances of Paralvinella polychaete worms ( $P$. palmiformis, $P$. pandorae and $P$. sulfincola) is inversely proportional to the relative abundance of Lepetodrilus fucensis. These worms aggregate at the fluid exit point. Perhaps Paralvinella, known to possess novel sulphide detoxification pathways (Martineu et al. 1997), better tolerates periodic exposure to higher temperature fluids with high sulphide levels. The worms may also be able to physically displace the gastropods.

\section{Space competition}

Temperatures above $15^{\circ} \mathrm{C}$ may trigger avoidance of vent flows that present physiologically limiting conditions. Differences between habitat occupation and temperature preferences by these 3 gastropods suggest further studies need to investigate the role of other abiotic and biotic factors in habitat selection. For example, Lepetodrilus fucensis and Depressigyra globulus are abundant in near-vent habitats despite a preference for in-vent temperatures. These peripheral individuals may be displaced to lower quality habitats by competition for food or space. The high densities of L. fucensis and D. globulus measured in this study suggest density-dependent competition may force the use of a variety of habitats besides those preferred (Rosenzweig \& Abramsky 1985). Provanna variabilis is also probably excluded from in-vent habitats by the other gastropods.

\section{Responses to other factors}

Temperature likely interacts with other factors such as flow vigour (Sarrazin et al. 1997) in habitat selection. A pilot on-ship experiment introduced 60 individuals from each of the 3 gastropod species to flows of $4.4 \mathrm{~cm}$ $\mathrm{s}^{-1}$ (surface pressure, $6^{\circ} \mathrm{C}$ ). Directional orientation was not observed (A. Bates unpubl. data). However, in flowing water, Lepetodrilus fucensis lifted its shell (similar to 'mushrooming' by littorines) and Depressigyra globulus and Provanna variabilis initiated random crawling patterns. Thus, an encounter with flowing fluid probably initiates movement and positioning. In addition, all 3 species are negatively geotaxic, Depressigyra globulus notably so. Geotaxic behaviour may serve to reorient individuals that fall off chimney structures and tubeworm bushes, as in the case of many intertidal gastropods that use geotaxism to maintain positions on the shore (Underwood 1979).

Hydrogen sulphide concentration is a principal factor correlated with faunal distributions (Sarrazin et al. 1999). Marcus et al. (2003) report a correlation between the relative abundance of Lepetodrilus fucensis and sulphide-to-heat ratio. Further, a shrimp species from Mid-Atlantic Ridge vents exhibits a chemosensory response to sulphide that may serve in orientating individuals to vent flows (Renninger et al. 1995). Gastropods may use multiple environmental cues in habitat selection.

\section{Broader implications}

Several studies examine time-series temperature measurements from probes positioned among vent animals in diffuse flows (Table 2). Maximum temperatures in these flows do not exceed $22^{\circ} \mathrm{C}$, unlike the extreme temperatures reported for alvinellid polychaetes (Chevaldonné et al. 1992, Chevaldonné 2000, 
Table 2. Summary data from studies at Pacific Ocean vent sites reporting timeseries of temperature at fixed positions in vent fluids where fauna are abundant. The measurement interval (Meas int) and duration (Meas dur) of each temperature series vary between studies; studies are ordered by decreasing interval. Times are at year (yr), month (mo), day (d), hour (h), minute (min) and second (s) scales. Maximum temperatures are less than $23^{\circ} \mathrm{C}$. Temperature range, the spread between maximum and minimum values, varies from 4 to $20^{\circ} \mathrm{C}$. Temperature change occurs at long and short scales. In some vent flows the overall temperature change (Overall $\Delta$ temp), the difference between start and end temperature, reached $15^{\circ} \mathrm{C}$. At shorter time scales within each record temperature changes of \pm several degrees are also evident (Short $\Delta$ temp). In all studies, temperature variability is high and unpredictable

\begin{tabular}{|c|c|c|c|c|c|c|}
\hline $\begin{array}{l}\text { Study } \\
\text { location }\end{array}$ & $\begin{array}{l}\text { Meas } \\
\text { int }\end{array}$ & $\begin{array}{l}\text { Meas } \\
\text { dur }\end{array}$ & $\begin{array}{c}\text { Temp } \\
\text { range } \\
\left({ }^{\circ} \mathrm{C}\right)\end{array}$ & $\begin{array}{c}\text { Overall } \\
\Delta \text { temp } \\
\left({ }^{\circ} \mathrm{C}\right)\end{array}$ & $\begin{array}{c}\text { Short } \\
\Delta \text { temp } \\
\left({ }^{\circ} \mathrm{C}\right)\end{array}$ & Source \\
\hline $\begin{array}{l}\text { Juan } \\
\text { de Fuca }\end{array}$ & $31 \mathrm{~h}$ & $7.2 \mathrm{mo}$ & $3-20$ & 15 & $7(\mathrm{mo})$ & $\begin{array}{l}\text { Martell et } \\
\text { al. (2002) }\end{array}$ \\
\hline $\begin{array}{l}\text { Juan } \\
\text { de Fuca }\end{array}$ & $30 \mathrm{~h}$ & $1 \mathrm{yr}$ & $\begin{array}{l}2-22 \\
3-16 \\
4-16 \\
3-12\end{array}$ & $\begin{array}{r}12 \\
10 \\
8 \\
6\end{array}$ & $\begin{array}{r}10(\mathrm{mo}) \\
6(\mathrm{mo}) \\
4(\mathrm{mo}) \\
4(\mathrm{mo})\end{array}$ & $\begin{array}{l}\text { Urcuyo } \\
(2000)\end{array}$ \\
\hline $\begin{array}{l}\text { Juan } \\
\text { de Fuca }\end{array}$ & $30 \min$ & $\begin{array}{r}15 \mathrm{~d} \\
3 \mathrm{~d}\end{array}$ & $\begin{array}{l}8-17 \\
4-12\end{array}$ & $\begin{array}{l}5 \\
1\end{array}$ & $\begin{array}{l}5(\mathrm{~h}) \\
5(\mathrm{~h})\end{array}$ & $\begin{array}{l}\text { This study } \\
\text { (Fig. 7) }\end{array}$ \\
\hline $\begin{array}{l}\text { Guaymas } \\
\text { Basin }\end{array}$ & $5 \mathrm{~min}$ & $\begin{array}{l}7 \mathrm{~d} \\
3 \mathrm{~d}\end{array}$ & $\begin{array}{l}3-9 \\
6-12\end{array}$ & $\begin{array}{l}5 \\
4\end{array}$ & $\begin{array}{l}2(\mathrm{~h}) \\
5(\mathrm{~h})\end{array}$ & $\begin{array}{l}\text { Chevaldonné } \\
(1996)\end{array}$ \\
\hline Galapagos & $15 \min$ & $3 d$ & $\begin{array}{l}2-15 \\
2-10\end{array}$ & $\begin{array}{l}5 \\
3\end{array}$ & $\begin{array}{r}10(\mathrm{~h}) \\
5(\mathrm{~h})\end{array}$ & $\begin{array}{l}\text { Johnson et al } \\
\text { (1988) }\end{array}$ \\
\hline $\begin{array}{l}\text { Juan } \\
\text { de Fuca }\end{array}$ & $5 \min$ & $30 \mathrm{~h}$ & $3-7$ & 1 & $3(\mathrm{~h})$ & $\begin{array}{l}\text { Tunnicliffe et } \\
\text { al. (1985) }\end{array}$ \\
\hline $\begin{array}{l}\text { East Pacific } \\
\text { Rise }\end{array}$ & $3.8 \mathrm{~min}$ & $47 \mathrm{~h}$ & $\begin{array}{l}2-8 \\
2-12 \\
3-16\end{array}$ & $\begin{array}{l}1 \\
1 \\
0\end{array}$ & $\begin{array}{l}2(\mathrm{~h}) \\
5(\mathrm{~h}) \\
8(\mathrm{~h})\end{array}$ & $\begin{array}{l}\text { Chevaldonné } \\
\text { et al. (1991) }\end{array}$ \\
\hline $\begin{array}{l}\text { Lau Back- } \\
\text { Arc Basin }\end{array}$ & & $27 \mathrm{~h}$ & $\begin{array}{l}2-4 \\
3-13 \\
4-18\end{array}$ & $\begin{array}{r}1 \\
2 \\
12\end{array}$ & $\begin{array}{r}1(\mathrm{~h}) \\
10(\mathrm{~h}) \\
8(\mathrm{~h})\end{array}$ & \\
\hline $\begin{array}{l}\text { North Fiji } \\
\text { Basin }\end{array}$ & & $27 \mathrm{~h}$ & $\begin{array}{l}5-12 \\
4-17 \\
8-22\end{array}$ & $\begin{array}{r}2 \\
5 \\
12\end{array}$ & $\begin{array}{l}5(\mathrm{~h}) \\
10(\mathrm{~h}) \\
8(\mathrm{~h})\end{array}$ & \\
\hline Galapagos & $32 \mathrm{~s}$ & $18 \mathrm{~d}$ & $\begin{array}{l}2-7 \\
4-20\end{array}$ & $\begin{array}{r}0 \\
10\end{array}$ & $\begin{array}{r}5(\mathrm{~h}) \\
15(\mathrm{~h})\end{array}$ & $\begin{array}{l}\text { Johnson et al } \\
\text { (1994) }\end{array}$ \\
\hline $\begin{array}{l}\text { East Pacific } \\
\text { Rise }\end{array}$ & $5.2 \mathrm{~s}$ & $5 \mathrm{~min}$ & $\begin{array}{l}3-7 \\
4-10 \\
4-12\end{array}$ & & $\begin{array}{l}3(\min ) \\
5(\min ) \\
7 \text { (min) }\end{array}$ & $\begin{array}{l}\text { Chevaldonné } \\
\text { et al. (1991) }\end{array}$ \\
\hline Galapagos & $0.5 \mathrm{~s}$ & $2 \min$ & $4-8$ & & $1(\mathrm{~s})$ & $\begin{array}{l}\text { Johnson et al } \\
\text { (1988) }\end{array}$ \\
\hline
\end{tabular}

month scales $\pm 10^{\circ} \mathrm{C}$ fluctuations are common and tidal spectra are present in most records (i.e. Tunnicliffe et al. 1985, Chevaldonné 1991, 1996, Urcuyo 2000). At longer scales, seismic activity can initiate unpredictable temperature and vent flow changes through fluid injection or re-routing (Johnson et al. 2000), cooling trends are also evident over the lifetime of a hydrothermal vent (Butterfield et al. 2003).

Thus, hydrothermal habitats offer a natural laboratory where fluctuations in fluid heat and associated characters are large, rapid and unpredictable. This study complements findings from other extreme environments where animal responses to highly variable thermal conditions have been examined; temperature responses play a large role in habitat selection. However, the variability presented by vent fluids may be unique. For example, although intertidal habitats oscillate up to $25^{\circ} \mathrm{C}$ diurnally (e.g. Helmuth \& Hofmann 2001), vent fluid temperatures fluctuate by several degrees at much shorter time scales. Further studies are needed to understand how these extreme fluctuations relate to body temperature variation, physiological stress and species patterns (Tomenack \& Helmuth 2002, Fitzhenry et al. 2004).

It is possible to manipulate animals from difficult environments to interpret responses to habitat variables. The congruence of field and lab approaches demonstrates that shipboard and deepsea experiments can yield robust insights. The gastropods manipulated in behavioural studies were responsive

Di Meo-Savoie et al. 2004). Although fluid temperatures in shrimp swarms range up to $40^{\circ} \mathrm{C}$, inducible stress proteins in the blind shrimp from the MidAtlantic Ridge also indicate an optimal thermal habitat for this species below $25^{\circ} \mathrm{C}$ (Ravaux et al. 2003). Point temperature measurements may be misleading.

Although temperatures are moderate in diffuse flows, variability is short-term, extreme, and unpredictable. Multiple degree temperature ranges (4 to $20^{\circ} \mathrm{C}$ ) were present in all time-series records and changes up to $\pm 15^{\circ} \mathrm{C}$ occur at short and long time scales (Table 2). At scales of seconds to minutes, turbulent mixing of emerging fluids with ambient seawater creates temperature fluctuations up to $\pm 7^{\circ} \mathrm{C}$. At hour to both shipboard and when returned to the seafloor where species-specific responses in shipboard experiments were replicable. These findings encourage the continued use of manipulative experiments to examine the role of abiotic and biotic factors as controls of small-scale patterns in vent species abundance.

\section{SUMMARY}

A combination of in vivo and in vitro studies of hot vent gastropods demonstrated the importance of temperature in habitat selection and, ultimately, the small-scale distribution patterns of 3 species. Gastro- 
pods responded to temperature gradients in the absence of other vent fluid characters and selected temperatures typical of their habitats. All 3 species exhibited moderate upper thermal preferences $\left(\sim 15^{\circ} \mathrm{C}\right)$ that corresponded with their in situ temperature limits, suggesting that warm flows may pose physiological constraints. Temperature is likely an important habitat cue for 2 species whose preferred thermal ranges approximated the fluid temperatures where each was most abundant. Our study indicates that abiotic variability is a key factor controlling the distributions of these species. Additionally, interspecies interactions probably modify species patterns. Relating animal responses to environmental variability using in situ and shipboard approaches will be important in further studies aiming to understand how habitat selection relates to vent faunal distributions.

Acknowledgements. We appreciate the skill and technical support of the ROPOS team, in particular K. Shepherd, in the design and implementation of experiments. D. Butterfield and I. MacDonald provided temperature data and K. Martell indicated the relationship in the time-lapse camera images. We are grateful for support by cruise participants: N. Kelly, K. Juniper, J. Marcus, A. Metaxas, A. Ortmann, and G. Yahel. The crew of the RV 'Brown' and RV 'Thompson' were supportive with last minute modifications to experiments. Technical assistance and conceptual insights were offered by T. Bird, J. Marcus, J. Rose and K. Skebo. Our field work was supported by NSERC Canada, the NOAA Vents Program, NSF DBI 0116203, NURC and graduate student scholarships to A. Bates from NSERC Canada and the families of Gordon Fields and Maureen de Burgh.

\section{LITERATURE CITED}

Bergquist D, Fleckenstein C, Szalai E, Knisel J, Fisher C (2004) Environment drives physiological variability in the cold seep mussel Bathymodiolus childressi. Limnol Oceanogr 49:706-715

Butterfield DA, Seyfried WE, Lilley MD (2003) Composition and evolution of hydrothermal fluids. In: Halbach PE, Tunnicliffe V, Hein JR (eds) Mass transfer in marine hydrothermal systems. Dahlem University Press, Berlin, p 123-162

Butterfield DA, Roe KK, Lilley MD, Huber J, Baross JA, Embley RW, Massoth GJ (2004) Mixing, reaction and microbial activity in sub-seafloor hydrothermal upflow zones: evidence from diffuse flow outcrops across the 1998 Axial Volcano sea-floor eruption area through time. In: Wilcock WSD, Delong EF, Kelley DS, Baross JA, Cary SC (eds) The subseafloor biosphere at mid-ocean ridges. Geophysical Monograph No. 144, American Geophysical Union, Washington, DC, p 269-289

Chapman MG (1999) Assessment of variability in responses of intertidal periwinkles to experimental transplantations. J Exp Mar Biol Ecol 236:171-190

Chapman MG (2000) Poor design of behavioural experiments gets poor results: examples from intertidal habitats. J Exp Mar Biol Ecol 250:77-95
Chevaldonné P (1996) Ecologie des cheminées hydrothermales actives. Thèse de Doctorat en Océanologie, Université de la Méditerranée, Marseille

Chevaldonné P (2000) Thermotolerance and the 'Pompeii worms'. Mar Ecol Prog Ser 208:293-295

Chevaldonné P, Desbruyères PD, Haitre ML (1991) Timeseries of temperature from three deep-sea hydrothermal vent sites. Deep-Sea Res 38:1417-1430

Chevaldonné P, Desbruyeres D, Childress J (1992) Some like it hot and some even hotter. Nature 359:593

de Burgh ME, Singla CL (1984) Bacterial colonization and endocytosis on the gill of a new limpet species from a hydrothermal vent. Mar Biol 84:1-6

Di Meo-Savoie CA, Luther GW, Cary SC (2004) Physicochemical characterization of the microhabitat of the epibionts associated with Alvinella pompejana, a hydrothermal vent annelid. Geochim Cosmochim Acta 68:2055-2066

Embley RW, Chadwick JWW, Clague D, Stakes D (1999) The 1998 eruption of Axial Volcano: multibeam anomalies and seafloor observations. Geophys Res Lett 26:3425-3428

Fitzhenry T, Halpin P, Helmuth B (2004) Testing the effects of wave exposure, site, behavior on intertidal mussel body temperatures: applications and limits of temperature logger design. Mar Biol 145:339-349

Fox M, Juniper SK, Vali H (2002) Chemoautotrophy as a possible nutritional source in the hydrothermal vent limpet Lepetodrilus fucensis. Cah Biol Mar 43:371-376

Fustec A, Desbruyères D, Juniper SK (1987) Deep-sea hydrothermal vent communities at $13^{\circ} \mathrm{N}$ on the East Pacific Rise microdistribution and temporal variations. Biol Oceanogr $4: 121-164$

Giere O, Borowski C, Prieur D (2003) Biological productivity in hydrothermal systems. In: Halbach PE, Tunnicliffe V, Hein JR (eds) Energy and mass transfer in marine hydrothermal systems. Dahlem University Press, Berlin, p 211-233

Heath A, Turner B, Davis W (1993) Temperature preferences and tolerances of 3 fish species inhabiting hyperthermal ponds on mangrove islands. Hydrobiologia 259:47-55

Helmuth B, Hofmann G (2001) Microhabitats, thermal heterogeneity, and patterns of physiological stress in the rocky intertidal zone. Biol Bull (Woods Hole) 201:374-384

Hessler RR, Smithey WM (1983) The distribution and community structure of megafauna at the Galapagos Rift hydrothermal vents. In: Rona PA, Bostrom K, Laubier L, Plenum KLS (eds) Hydrothermal processes at seafloor spreading centers. Plenum Press, New York, p 735-770

Jannasch HW (1995) Microbial interactions with hydrothermal fluids. In: Humphris SE, Zierenberg RA, Mullineaux LS, Thomson RE (eds) Seafloor hydrothermal systems: physical, chemical, biological and geological interactions. Geophysical Monograph No. 91, American Geophysical Union, Washington, DC, p 273-296

Johnson HP, Hutnak M, Dzlak RP, Fox CG, Urcuyo I, Cowen JP, Nabelek J, Fisher C (2000) Earthquake-induced changes in a hydrothermal system on the Juan de Fuca mid-ocean ridge. Nature 407:174-177

Johnson KS, Beehler CL, Sakamoto-Arnold CM, Childress JJ (1986) In situ measurements of chemical distributions in a deep-sea hydrothermal vent field. Science 231: $1139-1141$

Johnson KS, Childress JJ, Beehler CL (1988) Short-term temperature variability in the Rose Garden hydrothermal vent field: an unstable deep-sea environment. Deep-Sea Res 35:1711-1721

Johnson KS, Childress JJ, Beehler CL, Sakamoto CM (1994) Biogeochemistry of hydrothermal vent mussel communi- 
ties: the deep-sea analogue to the intertidal zone. DeepSea Res 41:993-1011

Lee RW (2003) Thermal tolerances of deep-sea hydrothermal vent animals from the Northeast Pacific. Biol Bull (Woods Hole) 205:98-101

Levesque C (2003) Les réseaux trophiques des sources hydrothermales de la dorsale Juan de Fuca, Pacifique Nord-Est. $\mathrm{PhD}$ dissertation, Université du Québec à Montréal

Luther GW, Rozan TF, Taillefert M, Nuzzio DB, Di Meo C, Shank TM, Lutz RA, Cary SC (2001) Chemical speciation drives hydrothermal vent ecology. Nature 410:813-816

Manly B (1991) Randomization and Monte Carlo methods in biology. Chapman and Hall, London

Marcus J, Tunnicliffe V (2002) Living on the edges of diffuse vents on the Juan de Fuca Ridge. Cah Biol Mar 43: 263-266

Marcus J (2003) Community ecology of hydrothermal vents at Axial Volcano, Juan de Fuca Ridge, northeast Pacific. $\mathrm{PhD}$ dissertation, University of Victoria

Martell KA, Tunnicliffe V, MacDonald IR (2002) Biological features of a buccinid whelk (Gastropoda, Neogastropoda) at the Endeavour ventfields of Juan de Fuca Ridge, Northeast Pacific. J Moll Stud 68:45-53

Martineu P, Juniper SK, Fisher CR, Massoth GJ (1997) Sulfide binding in the body fluids of hydrothermal vent Alvinellid polychaetes. Physiol Zool 70:578-588

McMahon RF (1990) Thermal tolerance, evaporative waterloss, air-water oxygen-consumption and zonation of intertidal prosobranchs - a new synthesis. Hydrobiologia 193: 241-260

Mullineaux LS, Fisher CR, Peterson CH, Schaeffer SW (2000) Tubeworm succession at hydrothermal vents: use of biogenic cues to reduce habitat selection error? Oecologia 123:275-284

Peck L (2004) Physiological flexibility: the key to success and survival for Antarctic fairy shrimps in highly fluctuating extreme environments. Freshw Biol 49:1195-1205

Pulgar J, Bozinovic F, Ojeda F (2005) Local distribution and thermal ecology of two intertidal fishes. Ecophysiology 142:511-520

Ravaux J, Gaill F, Bris NL, Sarradin P, Jollivet D, Shillito B (2003) Heat-shock response and temperature resistance in the deep-sea vent shrimp Rimicaris exoculata. J Exp Biol 206:2345-2354

Renninger G, Kass L, Gleeson R, Van Dover CL (1995) Sulfide as a chemical stimulus for deep-sea hydrothermal vent shrimp. Biol Bull (Woods Hole) 189:69-76

Rosenzweig ML, Abramsky Z (1985) Detecting densitydependent habitat selection. Am Nat 126:405-417

Sarrazin J, Juniper SK (1999) Biological characteristics of a hydrothermal edifice mosaic community. Mar Ecol Prog Ser 185:1-19

Editorial responsibility: Howard I. Browman (Associate Editor-in-Chief), Storebø, Norway
Sarrazin J, Juniper SK, Massoth G, Legendre P (1999) Physical and chemical factors influencing species distributions on hydrothermal sulfide edifices of the Juan de Fuca Ridge, northeast Pacific. Mar Ecol Prog Ser 190:89-112

Sarrazin J, Robigou V, Juniper SK, Delaney J (1997) Biological and geological dynamics over four years on a hightemperature sulfide structure at the Juan de Fuca Ridge hydrothermal observatory. Mar Ecol Prog Ser 153:5-24

Tivey MK, Bradley AM, Joyce TM, Kadko D (2002) Insights into tide-related variability at seafloor hydrothermal vents from time-series temperature measurements. Earth Planet Sci Lett 202:693-707

Tomenack L (2002) The heat-shock response: its variation, regulation and ecological importance in intertidal gastropods (genus Tegula). Int Comp Biol 42:797-807

Tomenack L, Helmuth B (2002) Physiological ecology of rocky intertidal organisms: a synergy of concepts. Int Comp Biol 42:771-775

Tsurumi M, Tunnicliffe V (2003) Tubeworm-associated communities at hydrothermal vents on the Juan de Fuca Ridge, northeast Pacific. Deep-Sea Res 50:611-629

Tunnicliffe V, Juniper SK (1990) Dynamic character of the hydrothermal vent habitat and the nature of sulphide chimney fauna. Prog Oceanogr 24:1-14

Tunnicliffe V, Juniper SK, de Burgh ME (1985) The hydrothermal vent community on Axial Seamount, Juan de Fuca Ridge. In: Jones $M$ (ed) The hydrothermal vents of the eastern Pacific Ocean: an overview, Vol 6. Bull Biol Soc Wash, p 453-464

Tunnicliffe V, Embley RW, Holden JF, Butterfield DA, Massoth G, Juniper SK (1997) Biological colonization of new hydrothermal vents following an eruption on Juan de Fuca Ridge. Deep-Sea Res 44:1627-1644

Underwood AJ (1979) The ecology of intertidal gastropods. Adv Mar Biol 16:111-210

Underwood AJ, Chapman MG, Crowe TP (2004) Identifying and understanding ecological preferences for habitat or prey. J Exp Mar Biol Ecol 300:161-187

Urcuyo IA (2000) Ecological physiology of the vestimentiferan tubeworm Ridgeia piscesae from diffuse flow environments on the Juan de Fuca Ridge. PhD dissertation, The Pennsylvania State University Eberly College of Science, University Park, PA

Van Dover CL, Lutz RA (2004) Experimental ecology at deepsea hydrothermal vents: a perspective. J Exp Mar Biol Ecol 300:273-307

Voss M, Utecht A, Wunnenberg W (2001) The dependence of thermopreferendum in Helix pomatia L. on air temperature. J Therm Biol 26:155-158

Williams G, Morritt D (1995) Habitat partitioning and thermal tolerance in a tropical limpet, Cellana grata. Mar Ecol Prog Ser 124:89-103

Submitted: April 4, 2005; Accepted: July 26, 2005

Proofs received from author(s): December 5, 2005 